\title{
MACROECONOMIC MODELLING OF THE CZECH ECONOMY USING COINTEGRATION VECTOR AUTOREGRESSION
}

\author{
[Makroekonomické modelování české ekonomiky pomocí kointegrované \\ vektorové autoregrese]
}

\author{
Radmila Stoklasová ${ }^{1}$ \\ ${ }^{1}$ Slezská univerzita, Obchodně podnikatelská fakulta, Univerzitní nám. 1934/3,733 40 Karviná \\ Email:stoklasova@opf.slu.cz
}

\begin{abstract}
This article aims to investigate the long-run structural cointegrated VAR model that relates to the core macroeconomic variables of the Czech economy to current and lagged values of a number of key foreign variables (6 domestic and 3 international) and 1 exogenous variable. This article aims to find cointegration equations for modeling the long-term equilibrium of economic relations in the Czech Republic in the analyzed period. Five long-run relationships are identified. The model includes purchasing power parity in relative version, money demand, a gap between domestic and foreign product, interest rate parity, Fisher inflation parity. A cointegration analysis showed that long-run structural equilibrium relationships correspond with empirical cointegration relationships, so the model used is suitable for a small open economy. Achieved empirical results are influenced by the fact that the Czech economy has undergone a currency crisis. The calculations used eViews software version 9 . The structural model is estimated for the Czech economy. The data used have the character of a quarterly time series in the period from Q1/2005 to Q4/2016. The data source was the Eurostat database, FRED, Czech National Bank and the Czech Statistical Office.
\end{abstract}

Keywords: ADF test of stationarity, cointegration relations, Czech economy, long-run structural vector autoregression, macroeconometric modelling, VECM model.

JEL classification: C10, E27

Doručeno redakci: 23.6.2017; Recenzováno: 26.7.2017; 12.8.2017; 11.9.2017; Schváleno k publikování: 20.9.2017

\section{Úvod}

Modely kointegrované vektorové regrese (CVAR) věnují pozornost dynamice ekonomických veličin proto, že ekonomické teorie nabízejí závěry týkající se kointegrace časových řad. Hlavní myšlenka je, že ekonomické veličiny se krátkodobě odchylují od svých rovnovážných hodnot, zatímco $\mathrm{v}$ delším časovém horizontu jsou $\mathrm{k}$ těmto rovnováhám pritahovány. Dlouhodobě působí síly posunující rovnovážné stavy, to vede ke stochastickým vývojovým trendům, ale také působí síly, které přitahují veličiny $\mathrm{k}$ rovnováhám, a to vede ke kointegračním vztahům mezi nimi. Jak uvádí Hoover (2008) pro makroekonomické časové řady je charakteristická nestacionarita a kointegrovatelnost.

Modely CVAR začaly vznikat na přelomu 80 . a 90 . let minulého stolení a byly orientovány na ekonomiku USA, jak uvádí ve studiích Blanchard (1993) a King (1991). Ve studii Garrat a kol. (2003) autoři vytvořili model ekonomiky Spojeného království. Tento model obsahoval pět rovnovážných vztahů. Tyto vztahy byly odvozeny zekonomické teorie, a proto mají strukturální charakter. Kointegrační analýza ukázala, že dlouhodobým rovnovážným strukturálním vztahům odpovídají empiricky zjištěné kointegrační vztahy, takže použitý model je pro malou otevřenou ekonomiku vhodný. Podobná metodika byla použita v př́ípadě německé ekonomiky, jak uvádí Schneider a kol. (2008). Autoři testují totožný model na německých čtvrtletních datech za období 1991-2005. Rovněž v této práci byl použit VAR(2) model a byla zjištěna př́tomnost pěti kointegračních vztahů. Práce Assenmacher-Weschkeho (2008) je orientována na švýcarskou ekonomiku v období 1Q/1976 - 4Q/2006. I v této práci kointegrační 
testy indikují přítomnost pěti kointegračních vztahů. Práce Hančlové a kol. (2010) je orientována na českou ekonomiku v období 1Q/1995 - 4Q/2009 a opět potvrzuje přítomnost pěti kointegračních vztahů.

\section{Data}

Na základě ekonomické teorie, kterou uvádí ve své práci Obstfeld (1996) a ekonomického odvození vztahů (1)-(4) pro malou otevřenou ekonomiku použijeme pro odhadování $\operatorname{VAR}(p)$ modelu 9 endogenních proměnných, z toho 6 domácích a 3 zahraniční, a exogennní proměnnou cenu ropy, která představuje dlouhodobou vynucující proměnnou. Zdrojem dat byla databáze Eurostat, FRED, ČNB a ČSÚ.

Označení a význam proměnných:

$P P_{t}=\ln \left(P_{t}\right)$, kde $P_{t}$ je index domácí ceny průmyslových výrobců $(2005=100)$,

$P E_{t}=\ln \left(P 1_{t}\right)$, kde $P 1_{t}$ je index zahraniční ceny průmyslových výrobců Eurozóny $(2005=100)$, $P O I_{t}=\ln \left(P 3_{t}\right)$, kde $P 3_{t}$ je index cena ropy $(2005=100)$,

$Y_{t}=\ln \left(Y C_{t} / P_{t}\right)$, kde $Y C_{t}$ je domácí nominální HDP (v mil.Kč),

$Y E_{t}=\ln \left(Y 1_{t} / P 1_{t}\right)$, kde $Y 1_{t}$ je zahraniční nominální HDP v Eurozóně (v mil.EUR),

$E_{t}=\ln \left(E 1_{t}\right)$, kde $E 1_{t}$ je index nominálního devizového kurzu CZK/EUR $(2005=100)$,

$R_{t}=0,25 \ln \left(1+\left(R 1_{t} / 100\right)\right)$, kde $R 1_{t}$ je roční domácí úroková sazba (PRIBOR_1Y),

$R E_{t}=0,25 \ln \left(1+\left(R 2_{t} / 100\right)\right)$, kde $R 2_{t}$ je roční zahraniční úroková sazba (EURIB̈OR_1Y),

$M 2_{t}=\ln \left(M \_2 t\right)$, kde $M \_2$ je peněžní měnový agregát $M 2 \mathrm{v}$ mil.Kč,

$I N F_{t}=P S_{t}-P S_{t-1}$.

Pět rovnic reprezentujících dlouhodobé rovnovážné trajektorie makroekonomického vývoje:

$$
\begin{array}{rrr}
P P P: & P P_{t}-P E_{t}-E_{t}=b_{1}+\varepsilon_{1 t} \\
M D: & M 2_{t}-Y_{t}=b_{2}+\beta_{21} R_{t}+\beta_{22} Y_{t}+\varepsilon_{2 t} \\
G R: & Y_{t}-Y E_{t}=b_{3}+\varepsilon_{3 t} \\
I R P: & R_{t}-R E_{t}=b_{4}+\varepsilon_{4 t} \\
F I P: & R_{t}-I N F_{t}=b_{5}+\varepsilon_{5 t}
\end{array}
$$

V modelu se vyskytují: parita kupní síly v relativní verzi $(P P P)$, poptávka po penězích $(M D)$, mezera domácího a zahraničního produktu $(G R)$, parita domácích a zahraničních úrokových měr $(I R P)$, Fisherova inflační parita $(F I P)$.

\section{Domácí a zahraniční produkt}

V období 2005-2008 neprokazují obě časové řady stejný trend, jak je vidět na Obrázku 1 a Obrázku 2.

Obrázek 1: Vývoj logaritmu domácího produktu $Y C_{t}$

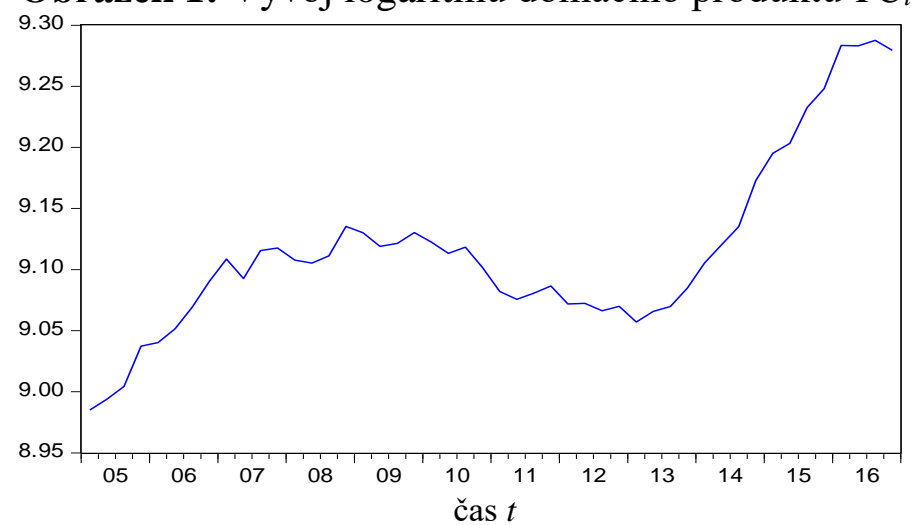

Zdroj: Webový portál: Český statistický úřad [online] [vid. 20.dubna 2017].

Dostupné z $<$ http://www.czso.cz> 
Obrázek 2: Vývoj logaritmu zahraničního produktu $Y 1_{t}$

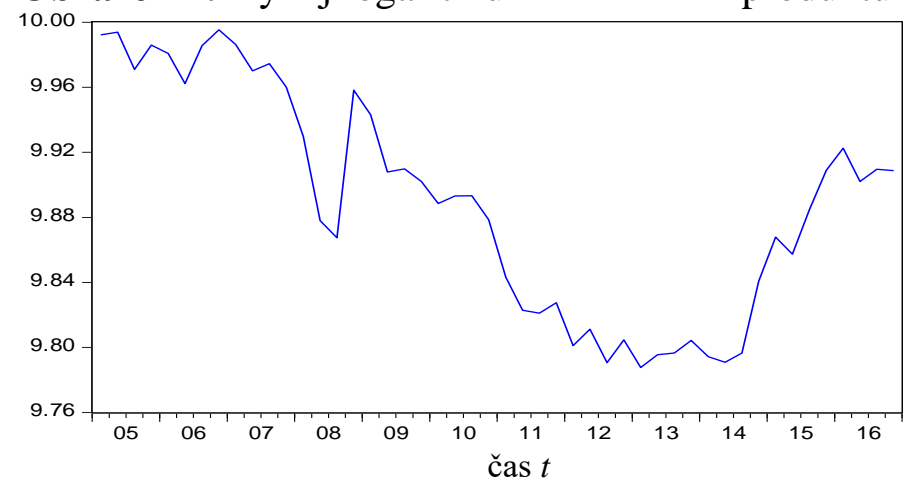

Zdroj: Webový portál: Eurostat database. [online] [vid. 20.dubna 2017].

Dostupné z < http://epp.eurostat.ec.europa.eu/portal/page/portal/statistics/search_database>

Jedná se o období, kdy v roce 2007 došlo k hypoteční krizi, která se rozšířila na finanční krizi. Vlády i centrální banky od záŕí 2008 realizovaly opatření na podporu finančního sektoru. Logaritmovaná časová řada zahraničního produktu vykazuje pokles v 3Q/2008 na hodnotu 9,86 a v 4Q/2008 nárůst na hodnotu 9,95. Začátkem roku 2009 finanční krize přechází do krize reálné ekonomiky. V období 2009-2012 obě proměnné prokazují klesající trend. V období 2013-2016 prokazují obě proměnné rostoucí trend, dochází k ekonomickému růstu.

\section{Domácí a zahraniční ceny}

Časové řady na Obrázku 3 ukazují vývoj logaritmů indexu domácí ceny $P P_{t}$ a indexu zahraniční ceny $P E_{t}$ průmyslových výrobců v období 2005-2016. Obě časové řady vykazují podobný charakter: v období $1 \mathrm{Q} / 2005$ - 3Q/2008 vykazují rostoucí trend, pokles nastal v 3Q/2008 $1 Q / 2009$ v časové řadě indexu zahraniční ceny průmyslových výrobců, v časové řadě indexu domácí ceny průmyslových výrobců tento pokles pokračoval až do 3Q/2009. V období 20102016 vykazují obě řady podobný trend, a jak je uvedeno dále, jsou obě časové řady nestacionární.

Obrázek 3: Vývoj logaritmů indexu domácí ceny $P P_{t}$ a zahraniční ceny $P E_{t}$ průmyslových výrobců

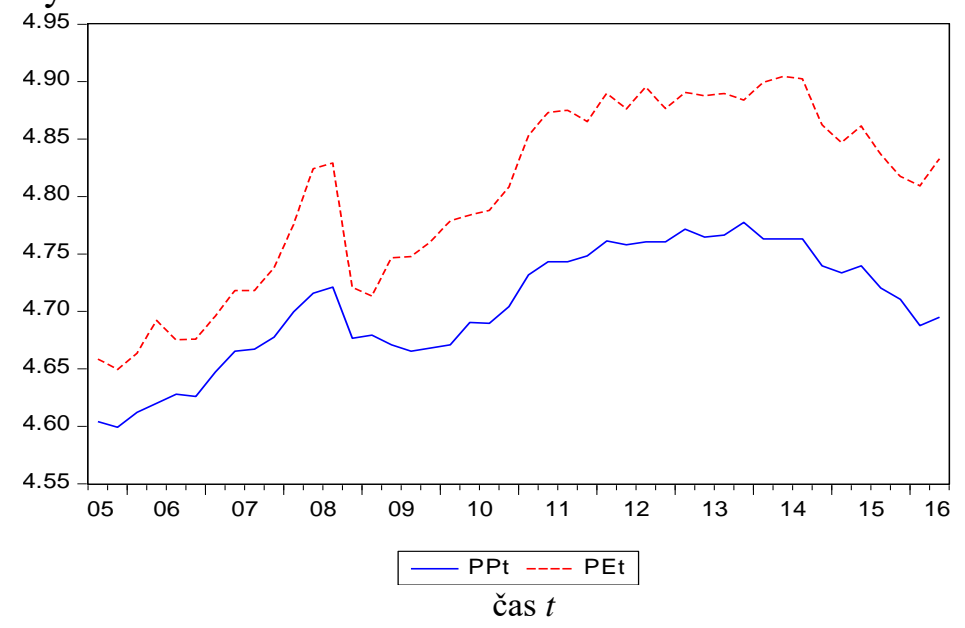

Zdroj: Webový portál: OECD: Main Economic Indicators . StatExtrats. [online] [vid. 20.dubna 2017].

Dostupné z $<$ http://stats.oecd.org/mei/>

\section{Makroekonomický model pro českou ekonomiku}

Druhá kapitola se zabývá odhadováním a testováním základního makroekonomického modelu pro českou ekonomiku za období 1Q/2005 - 4Q/2016. Obecnější teoretické informace o 
použitých modelech a metodice lze najít například v publikacích Arlt (2007) nebo Hančlová (2012). Kapitola je rozdělena na 5 částí. Nejprve se testuje stacionarita proměnných veličin VAR modelu. Druhým krokem je stanovení řádu VAR modelu a jeho diagnostika. Součástí této podkapitoly je také testování slabé exogenity ceny ropy. Ve třetím kroku se testují kointegrační vztahy pro $\operatorname{VAR}(p)$ model pomocí Johansenovy metody a stanoví se počet kointegračních vztahů. Čtvrtým krokem procedury je odhadnout $\operatorname{VECM}(p-1)$ model za předpokladu existence $r$ kointegračních vztahů, což je uvedeno je třetí kapitole. V závěru třetí kapitoly jsou uvedeny také rovnice pro dlouhodobé rovnovážné vztahy.

Př́pravnou fází odhadování VAR modelu je testování stacionarity proměnných zahrnutých do modelu, případně jejich prvních diferencí. Výsledky testů pro všechny proměnné zachycuje Tabulka 1. Pro testování stacionarity byl použit Dickeyův-Fullerův test (ADF). Druhý sloupec dává informaci o typu modelu testování jednotkového kořene $(\mathrm{n}=$ bez trendu a úrovňové konstanty $/ \mathrm{c}=$ konstanta $/ \mathrm{c}+\mathrm{t}=$ úrovňová konstanta a trend), třetí sloupeček obsahuje vypočtenou T-statistiku, následující sloupeček obsahuje odpovídající hladinu statistické významnosti. V posledním sloupci je výsledek testování: $\mathrm{N}=$ nestacionární, ( $\mathrm{H}_{0}$ nezamítáme), $\mathrm{S}=$ stacionární $\left(\mathrm{H}_{0}\right.$ zamítáme).

Tabulka 1: Testování jednotkového kořene proměnných v úrovních a v prvních diferencích

\begin{tabular}{|c|c|c|c|c|c|c|c|c|c|}
\hline proměnná & $\mathrm{n} / \mathrm{c} / \mathrm{c}+\mathrm{t}$ & T-stat & significance & výsledek & proměnná & $\mathrm{n} / \mathrm{c} / \mathrm{c}+\mathrm{t}$ & $\mathrm{T}$-stat & significance & výsledek \\
\hline$P P_{\mathrm{t}}$ & $\mathrm{c}+\mathrm{t}$ & $-0,698$ & 0,967 & $\mathrm{~N}$ & $D\left(P P_{t}\right)$ & $\mathrm{n}$ & $-5,466$ & 0,000 & $\mathrm{~S}$ \\
\hline$P E_{\mathrm{t}}$ & $\mathrm{c}+\mathrm{t}$ & $-1,538$ & 0,802 & $\mathrm{~N}$ & $D\left(P E_{\mathrm{t}}\right)$ & $\mathrm{n}$ & $-5,812$ & 0,000 & $\mathrm{~S}$ \\
\hline$P O I_{\mathrm{t}}$ & $\mathrm{c}+\mathrm{t}$ & $-2,381$ & 0,384 & $\mathrm{~N}$ & $D\left(P O I_{\mathrm{t}}\right)$ & $\mathrm{n}$ & $-6,592$ & 0,000 & $\mathrm{~S}$ \\
\hline$Y_{\mathrm{t}}$ & $\mathrm{c}+\mathrm{t}$ & $-3,076$ & 0,125 & $\mathrm{~N}$ & $D\left(Y_{\mathrm{t}}\right)$ & $\mathrm{c}$ & $-4,754$ & 0,000 & $\mathrm{~S}$ \\
\hline$Y E_{\mathrm{t}}$ & $\mathrm{c}+\mathrm{t}$ & $-0,899$ & 0,947 & $\mathrm{~N}$ & $D\left(Y E_{\mathrm{t}}\right)$ & $\mathrm{n}$ & $-6,334$ & 0,000 & $\mathrm{~S}$ \\
\hline$E_{\mathrm{t}}$ & $\mathrm{c}+\mathrm{t}$ & $-3,056$ & 0,127 & $\mathrm{~N}$ & $D\left(E_{\mathrm{t}}\right)$ & $\mathrm{n}$ & $-3,456$ & 0,054 & $\mathrm{~N}$ \\
\hline$R_{\mathrm{t}}$ & $\mathrm{c}+\mathrm{t}$ & $-1,043$ & 0,263 & $\mathrm{~N}$ & $D\left(R_{\mathrm{t}}\right)$ & $\mathrm{n}$ & $-4,191$ & 0,001 & $\mathrm{~S}$ \\
\hline$R E_{\mathrm{t}}$ & $\mathrm{c}+\mathrm{t}$ & $-2,165$ & 0,497 & $\mathrm{~N}$ & $D\left(R E_{\mathrm{t}}\right)$ & $\mathrm{n}$ & $-5,507$ & 0,000 & $\mathrm{~S}$ \\
\hline$M 2_{t}$ & $\mathrm{c}+\mathrm{t}$ & $-2,623$ & 0,272 & $\mathrm{~N}$ & $D\left(M 2_{t}\right)$ & $\mathrm{c}$ & $-9,739$ & 0,000 & $\mathrm{~S}$ \\
\hline$I N F_{\mathrm{t}}$ & $\mathrm{n}$ & $-0,879$ & 0,328 & $\mathrm{~N}$ & $D\left(I N F_{\mathrm{t}}\right)$ & $\mathrm{n}$ & $-3,264$ & 0,062 & $\mathrm{~N}$ \\
\hline
\end{tabular}

Zdroj: vlastní výpočty, program eViews

Proměnné $\left(P P_{t} ; P E_{t} ; P O I_{t} ; Y_{t} ; Y E_{t} ; R_{t} ; R E_{t} ; M 2_{t}\right)$ pro VAR model vykazují vlastnosti nestacionarity prního řádu, tj. I(1) a proto mohou mezi těmito proměnnými existovat dlouhodobé kointegrační vztahy.

Dalším krokem je odhad $\operatorname{VAR}(p)$ modelu. Odhad modelu zahrnuje stanovení řádu $p$ pro zpoždění proměnných $\left(P P_{t} ; P E_{t} ; P O I_{t} ; Y_{t} ; Y E_{t} ; R_{t} ; R E_{t} ; M 2_{t}\right)$ ve vektorovém autoregresním modelu. Tato úrověň zpoždění bývá zpravidla stejná pro všechny rovnice VAR modelu. Vzhledem $\mathrm{k}$ souboru kvartálních dat byla uvažována délka zpoždění maximálně 4 . Tabulka 2 shrnuje výsledky na základě minimalizace vybraných kritérií: FPE: kritérium predikce chyby, AIC: Akaikovo informační kritérium, SC: Schwarz-Bayesovo informační kritérium, HQ: Hannan-Quinnovo informační kritérium a LR: testovací statistika poměrem věrohodnosti. 
Tabulka 2: Testování délky zpoždění VAR modelu dle vybraných kritérií

\begin{tabular}{|c|c|l|l|l|l|}
\hline Zpoždění & LR & FPE & AIC & SC & HQ \\
\hline 0 & NA & $2,46 \mathrm{e}-30$ & $-45,47474$ & $-45,15034$ & $-45,35443$ \\
\hline 1 & 602,9188 & $1,56 \mathrm{e}-36$ & $-59,79190$ & $-56,87231$ & $-58,70917$ \\
\hline 2 & $124,7745^{*}$ & $3,77 \mathrm{e}-37$ & $-61,50408$ & $-55,98931$ & $-59,45894$ \\
\hline 3 & 83,08560 & $2,14 \mathrm{e}-37$ & $-62,96792$ & $-54,85796$ & $-59,96036$ \\
\hline 4 & 82,95063 & $2,12 \mathrm{e}-38^{*}$ & $-67,59979 *$ & $-56,89466^{*}$ & $-63,62981^{*}$ \\
\hline
\end{tabular}

* označuje řád zpoždění vybraný daným kritériem

Zdroj: vlastní výpočty, program eViews

Většina těchto testů doporučuje řád zpoždění 4 s výjimkou LR kritéria, které doporučuje model VAR(2). Dále byl proveden Waldův test pro testování do zpoždění $p=1,2,3,4$ pro jednotlivé rovnice. Výsledky potvrdily výběr modelu VAR(4). Pro další úvahy byl zvolen model VAR(3). $\mathrm{K}$ tomuto závěru vedou tyto skutečnosti: srovnatelnost s podobnými empirickými studiemi pro anglickou, švýcarskou i německou ekonomiku, a dále skutečnost, že malý počet pozorování při $p=4$ by vedl k nižší vypovídající schopnosti odhadnutého modelu.

Článek se dále zabývá zkoumáním slabé exogenity proměnné cena ropy $P O I_{\mathrm{t}}$. Výsledky testování kauzality podle Grangera zachycuje Tabulka 3. Proměnná cena ropy je ve VAR modelu závislá na domácím GDP a také na všech endogenních proměnných v modelu VAR(3) na 5\% hladině významnosti, a proto ji nelze považovat za slabě exogenní proměnnou. Proměnná cena ropy bude vyloučena z modelu jako vynucující proměnná.

Tabulka 3: Testování slabé exogenity ceny ropy

\begin{tabular}{|l|l|l|l|}
\hline & Chi-sq & df & p-hodnota \\
\hline$M 2_{t}$ & 4,643332 & 3 & 0,2178 \\
\hline$P E_{t}$ & 0,566772 & 3 & 0,9040 \\
\hline$P P_{t}$ & 5,353063 & 3 & 0,1477 \\
\hline$R E_{t}$ & 1,635223 & 3 & 0,6514 \\
\hline$R_{t}$ & 1,479856 & 3 & 0,6869 \\
\hline$Y E_{t}$ & 3,200838 & 3 & 0,3617 \\
\hline$Y_{t}$ & 22,01445 & 3 & 0,0001 \\
\hline$A L L$ & 110,1927 & 3 & 0,0000 \\
\hline$Z d r O j:$ & 1 &
\end{tabular}

Zdroj: vlastní výpočty, program eViews

Výsledkem modelu české ekonomiky je VAR(3) model pro endogenní proměnné $\left(P P_{t} ; P E_{t} ; Y_{t}\right.$; $\left.Y E_{t} ; R_{t} ; R E_{t} ; M 2_{t}\right)$. Tento model bez restrikcí byl odhadnut pomocí ML metody maximální věrohodnosti, podobně jako uvádí Hančlová (2009).

Pro posouzení kvality modelu VAR(3) byly provedeny diagnostické testy. Tyto testy zahrnují splnění podmínek stacionarity, nekorelovanosti v odhadnuté reziduální složce a testování normality reziduální složky. Podmínka stacionarity modelu VAR(3) byla ověřena pomocí grafického znázornění převrácených hodnot kořenů odhadnutého autoregresního polynomu. Tyto hodnoty leží uvnitř jednotkového kruhu, tedy model VAR(3) je stacionární. Nekorelovanost reziduální složky odhadnutého modelu VAR(3) byla testována pomocí LM testu a tento test potvrzuje nekorelovanost reziduální složky (na 5\% hladině významnosti nezamítáme nulovou hypotézu nekorelovanosti reziduální složky). Testování normality reziduální složky bylo provedeno pomocí Jarque-Bera testu. Nulová hypotéza o normalitě reziduální složky nebyla na $5 \%$ hladině významnosti zamítnuta.

Ve třetím kroku se testuje počet kointegračních vztahů ve VAR(3) modelu pro endogenní proměnné $\left(P P_{t} ; P E_{t} ; Y_{t} ; Y E_{t} ; R_{t} ; R E_{t} ; M 2_{t}\right)$ pomocí Johansonovy metody, jak uvádí Enders 
(2001) a Johansen (1995). Tabulka 4 potvrzuje existenci 5 kointegračních vztahů pro VECM(2). Jedná se o model, který zahrnuje neomezenou úrovňovou konstantu a omezenou trendovou složku.

Tabulka 4: Výsledky kointegrační analýzy

\begin{tabular}{|l|l|l|l|l|}
\hline $\begin{array}{l}\text { H0: Počet } \\
\text { kointegračních vztahů }\end{array}$ & $\begin{array}{l}\text { Vlastní } \\
\text { číslo }\end{array}$ & $\begin{array}{l}\text { Hodnota } \\
\text { statistiky }\end{array}$ & $\begin{array}{l}\text { Kritická } \\
\text { hodnota }\end{array}$ & p-hodnota \\
\hline žádný * & 0,834555 & 269,5137 & 150,5585 & 0,0000 \\
\hline nejvýše $1 *$ & 0,702056 & 188,5534 & 117,7082 & 0,0000 \\
\hline nejvýše 2* & 0,590460 & 134,0652 & 88,80380 & 0,0000 \\
\hline nejvýše 3* & 0,576250 & 93,89277 & 63,87610 & 0,0000 \\
\hline nejvýše 4* & 0,500881 & 55,25521 & 42,91525 & 0,0019 \\
\hline nejvýše 5 & 0,288627 & 23,98425 & 25,87211 & 0,0843 \\
\hline
\end{tabular}

* označuje zamítnutí nulové hypotézy na hladině významnosti 0,05

Zdroj: vlastní výpočty, program eViews

\section{Kointegrační VECM s restrikcemi a rovnice dlouhodobých vztahů}

Dalším krokem odhadovací procedury je odhadnout $\operatorname{VECM}(p-1)$ model, tedy $\operatorname{VECM}(2)$, za předpokladu 5 kointegračních vztahů. Verze modelu VECM(2) obsahuje restrikce uvedené v následující Tabulce 5. Jedná se o 28 restrikcí v matici a ještě o restrikce: $\beta_{1}+\beta_{2}=0 ; \beta_{5}+$ $\beta_{6}=0$, které v rovnici parity kupní síly v relativní verzi $(P P P)$ zajistí existenci výrazu $\left(Y_{t}-\right.$ $\left.Y E_{t}\right)$, a v rovnici pro mezeru domácího a zahraničního produktu $(G R)$ bude výraz $\left(R_{t}-R E_{t}\right)$.

Tabulka 5: Restrikce

\begin{tabular}{|c|c|c|c|c|c|c|c|}
\hline & $M 2_{t}$ & $P E_{t}$ & $P P t$ & $R E_{t}$ & $R t$ & $Y E_{t}$ & $Y t$ \\
\hline$P P P$ & 0 & -1 & 1 & 0 & 0 & $\beta_{1}$ & $\beta_{2}$ \\
\hline$M D$ & 1 & 0 & 0 & 0 & $\beta_{3}$ & 0 & $\beta_{4}$ \\
\hline$G R$ & 0 & 0 & 0 & $\beta_{5}$ & $\beta_{6}$ & $\beta_{7}$ & 1 \\
\hline$I R P$ & 0 & 0 & 0 & -1 & 1 & 0 & 0 \\
\hline$F I P$ & 0 & 0 & -1 & 0 & 1 & 0 & 0 \\
\hline
\end{tabular}

Zdroj: vlastní výpočty, program eViews

Podmínky stacionarity modelu $\operatorname{VECM}(2)$ zobrazuje Obrázek 4, kde jsou znázorněny převrácené hodnoty kořenů odhadnutého autoregresního polynomu. Tyto hodnoty leží uvnitř jednotkového kruhu, tedy model $\operatorname{VECM}(2)$ je stacionární.

Obrázek 4: Převrácené hodnoty kořenů autoregresního polynomu modelu VECM(2)

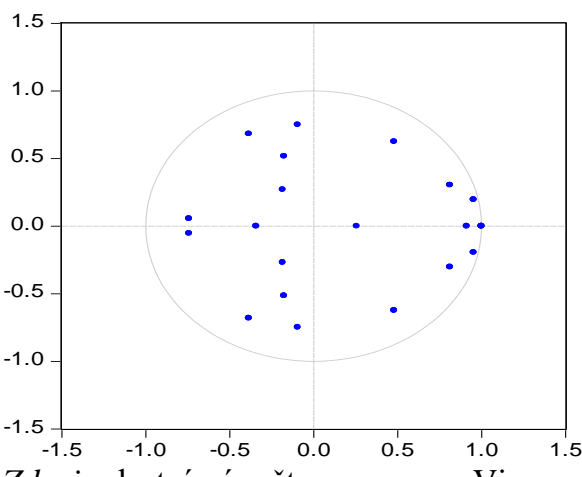

Zdroj: vlastní výpočty, program eViews

Nekorelovanost reziduální složky odhadnutého modelu VECM(2) byla testována pomocí LM testu. Hodnoty testu zachycuje Tabulka 6. Tento test potvrzuje nekorelovanost reziduální 
složky (na 5\% hladině významnosti nezamítáme nulovou hypotézu nekorelovanosti reziduální složky).

Tabulka 6: Testování autokorelace reziduální složky VECM(2)

\begin{tabular}{|l|l|l|}
\hline Zpoždění & LM-Statistika & p-hodnota \\
\hline 1 & 46,55831 & 0,5727 \\
\hline 2 & 60,18466 & 0,1314 \\
\hline 3 & 63,11026 & 0,0848 \\
\hline 4 & 57,93207 & 0,1790 \\
\hline
\end{tabular}

Zdroj: vlastní výpočty, program eViews

Testování normality reziduální složky bylo provedeno pomocí Jarque-Bera testu. Výsledky testu jsou v Tabulce 7 . Nulová hypotéza o normalitě reziduální složky nebyla na 5\% hladině významnosti zamítnuta.

Tabulka 7: Testování normality reziduální složky $\operatorname{VECM(2)~}$

\begin{tabular}{|l|l|l|l|}
\hline Komponenty & Jarque-Bera & df & p-hodnota \\
\hline 1 & 5,501451 & 2 & 0,0639 \\
\hline 2 & 5,557621 & 2 & 0,0621 \\
\hline 3 & 0,288532 & 2 & 0,8657 \\
\hline 4 & 1,312755 & 2 & 0,5187 \\
\hline 5 & 0,730902 & 2 & 0,6939 \\
\hline 6 & 2,322275 & 2 & 0,3131 \\
\hline 7 & 0,097435 & 2 & 0,9525 \\
\hline Systém rovnic & 15,81097 & 14 & 0,3251 \\
\hline
\end{tabular}

Zdroj: vlastní výpočty, program eViews

Dále bylo provedeno testování nulové hypotézy o homoskedasticitě reziduální složky. Nulová hypotéza nebyla zamítnuta na 5\% hladině významnosti.

Tabulka 8 ukazuje vypovídací schopnost jednotlivých odhadnutých rovnic ve VECM(2) s restrikcemi. Průměrná úroveň adj. $\mathrm{R}^{2}=0,628$ a pohybuje se $\mathrm{v}$ intervalu od 0,427 (rovnice domácího výstupu ekonomiky) do 0,755 (rovnice zahraničního výstupu ekonomiky). Tyto míry vysvětlení jsou lepší ve srovnání s anglickou studií Garratta (2003), nebo švýcarskou studií Assenmacher-Weschkeho (2008).

Tabulka 8: Koeficienty determinace pro odhadnuté rovnice výsledného modelu

\begin{tabular}{|l|c|c|c|c|c|c|c|}
\hline & $D\left(M 2_{t}\right)$ & $D(P E t)$ & $D(P P t)$ & $D\left(R E_{t}\right)$ & $D\left(R_{t}\right)$ & $D\left(Y E_{t}\right)$ & $D\left(Y_{t}\right)$ \\
\hline $\mathrm{R}^{2}$ & 0,795 & 0,858 & 0,766 & 0,706 & 0,861 & 0,861 & 0,675 \\
\hline Adj. $\mathrm{R}^{2}$ & 0,641 & 0,751 & 0,588 & 0,484 & 0,754 & 0,755 & 0,427 \\
\hline
\end{tabular}

Zdroj: vlastní výpočty, program eViews

Lze tedy shrnout, že odhad finální verze $\operatorname{VECM}(2)$ s restrikcemi je stabilní, s relativně vysokou vypovídací schopností. Reziduální složka není korelována, nebyla prokázána heteroskedasticita reziduální složky a také nebyla prokázána nenormalita reziduální složky.

Rovnice (6)-(10) shrnují výsledky odhadu kointegračního VECM(2) s 28 restrikcemi (uvedenými v Tabulce 5) pro modelování dlouhodobých rovnovážných vztahů pro Českou republiku ve zkoumaném období. Všechny regresní koeficienty jsou statisticky významné na $5 \%$ hladině významnosti. 


$$
\begin{array}{rrr}
P P P: & P P_{t}-P E_{t}=0,953+1,174\left(Y_{t}-Y E_{t}\right)+\varepsilon_{1 t} \\
M D: & M 2_{t}=10,818-6,668 R_{t}+0,418 Y_{t}+\varepsilon_{2 t} \\
\text { GR: } & \mathrm{Y}_{\mathrm{t}}=-2,63-17,743\left(\mathrm{R}_{\mathrm{t}}-\mathrm{RE}_{\mathrm{t}}\right)+1,173 \mathrm{YE}_{\mathrm{t}}+\varepsilon_{3 \mathrm{t}} \\
\text { IRP: } & R_{t}-R E_{t}=0,00354+\varepsilon_{4 t} \\
\text { FIP: } & R_{t}-P P_{t}=-4,706+\varepsilon_{5 t}
\end{array}
$$

\section{Závěr}

Tento článek se zabýval modelováním strukturálních dlouhodobých rovnovážných vztahů pro českou ekonomiku v období 2005-2016. Cílem článku bylo nalezení kointegračních rovnic pro modelování dlouhodobých rovnovážných ekonomických vztahů pro Českou republiku ve zkoumaném období. Bylo použito modelování pomocí kointegračních vektorového autoregresního modelu s restrikcemi pro endogenní proměnné $\left(P P_{t} ; P E_{t} ; Y_{t} ; Y E_{t} ; R_{t} ; R E_{t} ; M 2_{t}\right)$. Odhad modelu VECM(2) s restrikcemi je stabilní, relativně s vysokou vypovídací schopností. Tento model obsahuje pět kointegračních vztahů s 28 restrikcemi. Reziduální složka není korelována, nebyla prokázána heteroskedasticita reziduální složky a také nebyla prokázána nenormalita reziduální složky.

V první rovnici $P P P(6)$ je prokázán uvažovaný vliv mezinárodní mezery produktu (koeficient $1,17 \%)$ na paritě kupní síly $(P P P)$. Stejně jako v př́ibuzných zahraničních studiích (britská studie Garrat a kol. (2003), německá studie Schneider a kol. (2007)) není možno ani zde zamítnout hypotézu o platnosti relativní verze $P P P$ v dlouhém období. $Z$ druhé rovnice $M D$ (7) vyplývá, že poptávka po peněžních zůstatcích je negativně závislá na domácí nominální úrokové míře (koeficient $6,67 \%$ ) a pozitivně závislá na domácím reálném produktu (koeficient $0,42 \%$ ), což odpovídá peněžní teorii. Peněžní agregát $M 2_{t}$ je dostatečně velký na to, aby se vyrovnal s př́ípadnými změnami v nástrojích používaných $\mathrm{k}$ finančnímu zprostředkování. Třetí rovnice $G R(8)$ ukazuje, že na reálný domácí produkt působí úrokový rozdíl $\left(R_{t}-R E_{t}\right)$ (koeficient 17,74 \%) a také zahraniční produkt (koeficient 1,17\%). Jednoprocentní nárůst $\left(R_{t}-\right.$ $\left.R E_{t}\right)$ vede k téměř osmnáctinásobnému poklesu domácího produktu. Vliv $\left(R_{t}-R E_{t}\right)$ na domácí produkt je v souladu s teorií. Britští i němečtí autoři dospěli ke stejnému tvrzení. Poslední dvě rovnice IRP (9) a FIP (10) jsou v souladu s hodnotami zjištěnými pro vyspělé země s dlouhou tradicí tržního hospodářství. Pokud jde o paritu domácí a zahraniční úrokové míry, britští autoři odhadují velikost konstanty na 0,0058 a němečtí autoři na 0,002 .

Porovnáním výsledků tohoto článku s výsledky studie Hančlové a kol. (2010), která je orientována na českou ekonomiku v období 1Q/1995 - 4Q/2009, dospějeme k následujícím závěrům. V rovnicích pro: paritu kupní síly v relativní verzi $(P P P)$, poptávku po penězích $(M D)$, paritu domácích a zahraničních úrokových měr $(I R P)$ a Fisherovu inflační paritu $(F I P)$ bylo dosaženo podobných výsledků. Práce se odlišují ve třetí rovnici pro mezeru domácího a zahraničního produktu $(G R)$, kde autoři Hančlová a kol. (2010) dospěli k závěru, že vliv úrokového diferenciálu byl sice statisticky významný, ale s opačným znaménkem, než očekává ekonomická teorie. Autoři Hančlová a kol. (2010) uvádějí, že jednoprocentní nárůst $\left(R_{t}-R E_{t}\right)$ vede $\mathrm{k}$ téměř osmnáctinásobnému růstu domácího produktu.

Použitý model pro malou otevřenou ekonomiku je teoreticky i empiricky konzistentní, protože odhadované parametry mají rozumná znaménka i hodnoty. Empirické výsledky jsou ovlivněny tím, že česká ekonomika prodělala ve sledovaném období měnovou krizi vyznačující se netypickým chováním úrokových sazeb, peněžních ukazatelů, měnového kurzu a dalších indikátorů. Měnová krize také ovlivnila interakce mezi zkoumanými proměnnými. 


\section{Poděkování}

Tento článek vznikl za podpory Ministerstva školství, mládeže a tělovýchovy ČR v rámci Institucionální podpory na dlouhodobý koncepční rozvoj výzkumné organizace v roce 2017.

\section{Literatura}

[1] ARLT, J. a M. ARLTOVÁ, 2007. Ekonomické časové řady. Praha: Grada Publishing. ISBN 978-80-247-1319-9.

[2] ASSENMACHER - WESCHKE, K. and M. H. PESARAN, 2008. A VECX model of the Swiss economy. CESifo Working Paper Series, No. 2281. Cambridge: University of Cambridge. ISSN 1661-1438. Available at SSRN: http://ssrn.com/abstract=1112545

[3] BLANCHARD, O. J. and D. QUAH, 1993. The dynamic effects of aggregate demand and supply disturbances. The American Economic Review 83(3), p.653-658.

[4] ENDERS, W. and P. L. SIKLOS, 2001. Cointegration and threshold adjustment. Journal of Business \& Economic Statistics 19(2), p.166-176.

[5] GARRATT, A., et al., 2003. A long run structural macroeconometric model of the UK. In: K. LEE, M. H. PESARAN, Y. SHIN, eds. The Economic Journal 113(487), p. 412-455. ISSN 0013-0133.

[6] HANČLOVÁ, J., 2009. Kvartální makroekonomický model české ekonomiky. In: Aktuální aspekty české a světové ekonomiky. Liberec: Technická univerzita Liberec, s.138147. ISBN 978-80-7372-536-5.

[7] HANČLOVÁ, J., I. KUBICOVÁ, M. MACHÁČEK, A. MELECKÝ, L. MELECKÝ, J. NEVIMA a J. RAMÍK, 2010. Makroekonometreické modelování české ekonomiky a vybraných ekonomik EU. VŠB-TU Ostrava, s.31-88. ISBN 978-80-248-2353-9.

[8] HANČLOVÁ, J., 2012. Ekonometrické modelování: klasické přistupy s aplikacemi. Praha: Professional Publishing. ISBN 978-80-7431-088-1.

[9] HOOVER,K. D., S. JOHANSEN and K. JUSELIUS, 2008. Allowing the data to speak freely: The macroeconometrics of the cointegrated vector autoregression. The American Economic Review 98(2), p.251-255.

[10] JOHANSEN, S., 1995. Likelihood-based Inference in Cointegrated Vector Autoregressive Models. Oxford: Oxford University Press. ISBN 9780198774501.

[11] KING, R. G., et al., 1991. Stochastic trends and economic fluctuations. In: CH. I. PLOSSER, J. H. STOCK, M. W. WATSON, eds. The American Economic Review 81(4), p.819-840.

[12] OBSTFELD, M. and K. ROGOFF, 1996. Foundations of International Macroeconomics. Cambridge: MIT Press.

[13] SCHNEIDER, E., P. CHEN and J. FROHN, 2008. A long-run structural macroeconometric model for Germany: An empirical note. Economics: The Open-Access, Open-Assessment E-Journal 2, 1-12. Available at: http://dx.doi.org/10.5018/economicsejournal.ja.2008-16 